\title{
The reproductive cycle, condition index and biochemical composition of the horse-bearded mussel Modiolus barbatus
}

\author{
Ivona Mladineo $\cdot$ Melita Peharda $\cdot$ \\ Stjepan Orhanović · Jakša Bolotin . \\ Maja Pavela-Vrančić · Barbara Treursić
}

Received: 4 February 2006/Revised: 1 February 2007 / Accepted: 5 February 2007/Published online: 10 March 2007

(C) Springer-Verlag and AWI 2007

\begin{abstract}
The horse-bearded mussel Modiolus barbatus (Linneus, 1758) is an important edible bivalve in the Adriatic Sea; its population is especially large in the Mali Ston Bay area, where the species is present at depths up to $8 \mathrm{~m}$. In order to assess the sustainable exploitation rate for this species, as well as to estimate its potential capacity for a sustainable aquaculture production, we determined the species' reproductive cycle along with its nutrient storage strategy, employing histological and biochemical methods. The population shows significantly more females than males, and no hermaphrodites. The smallest adult individual, an active male, was $16.0 \mathrm{~mm}$ in length, suggesting that sexual maturation starts around this length. While the period between January and February is characterized by sexual repose, early and late stages of gametogenesis were found between March and May, and spawning peaked from June till August. The increase of oocyte diameter followed the same trend. A significant positive correlation was
\end{abstract}

Communicated by H.-D. Franke.

I. Mladineo $(\bowtie) \cdot$ M. Peharda

Institute of Oceanography and Fisheries,

Šetalište Ivana Meštrovića 63,

21000 Split, Croatia

e-mail: mladineo@izor.hr

S. Orhanović · M. Pavela-Vrančić · B. Treursić

PMF Faculty of Natural Sciences,

Mathematics and Education,

N. Tesle 12, 21000 Split, Croatia

J. Bolotin

Institute for Marine and Coastal Research,

Kneza Damjana Jude 12,

20000 Dubrovnik, Croatia observed between gonad index and temperature, and a negative correlation between gonad index and salinity. Oscillations of stored nutrients were tightly coupled with the gametogenic cycle.

Keywords Reproductive cycle - Horse-bearded mussel · Modiolus barbatus . Adriatic Sea

\section{Introduction}

Among bivalves in the Adriatic Sea, the horse-bearded mussel Modiolus barbatus (Linneus, 1758) stands as an important edible species, harvested all year around, primarily by local inhabitants (Benović 1997). It occurs from the British Isles south to Mauritania, West Africa and throughout the Mediterranean (Poppe and Goto 1993). The Mali Ston Bay area, which is the most productive bivalve aquaculture area in the eastern Adriatic, exhibits a large population of the species. It is present throughout the bay at depths up to $8 \mathrm{~m}$, forming mussel beds along with the Noah's Arc (Arca noae L.), whose reproduction was described recently (Peharda et al. 2006).

Horse-bearded mussel mean density in the Mali Ston Bay is around 13 ind. $/ \mathrm{m}^{2}$ (maximum density, recorded between 2 and $3 \mathrm{~m}$, is up to $115 \mathrm{ind} . / \mathrm{m}^{2}$ ) (Peharda et al. 2003). Exploitation of the natural stocks is uncontrolled which might put considerable pressure on the sustainability of this action. The aim of the present study was to determine and evaluate the dynamics of the species' reproductive cycle along with its nutrient storage strategy. Such data are necessary for assessing sustainable exploitation rates for this species, as well as for estimating its potential capacity for sustainable aquaculture production (Turollo et al. 2002). 
Presently only two bivalve species, the European flat oyster (Ostrea edulis) and the black mussel (Mytilus galloprovincialis) are commercially cultured in this bay. Introduction of other bivalve species into aquaculture production would be of interest to the local population and the tourism industry, and $M$. barbatus is one of the potential candidates.

A regular supply of seed from the wild is a crucial element in the aquaculture of bivalves, however it necessitates knowledge of the population's reproductive cycle and the spawning process (Gosling 2003; Gribben et al. 2004). Although the reproductive biology of mytilids from different habitats has been investigated in previous studies (Thompson 1984; Lepennec 1997; Darrigran et al. 1999; Sgro et al. 2002; Maloy et al. 2003), no data are available on the seasonality of gonad development, length at sexual maturity and sex ratios of M. barbatus.

The paper describes the reproductive cycle of M. barbatus from the Mali Ston Bay, Adriatic Sea. The timing of reproductive development and spawning of M. barbatus are determined from histological preparations using qualitative and quantitative techniques. Sex ratios, developmental stage of gonads, mean gonadal index, diameter of oocytes, condition index are described and analyzed as to their implications to the development of a $M$. barbatus aquaculture production. As marine bivalves show a seasonal cycle of energy storage and utilization closely related to reproductive activity, Modiolus biochemical composition was determined to asses its energetic path that could have direct impact on the potential rearing of the species.

\section{Methods}

The reproductive cycle and the condition index of $M$. barbatus in the Mali Ston Bay, south Adriatic Sea (Fig. 1) were studied from January to December 2004. Mussels were collected once a month using SCUBA at 3-5 m depth. Lengths of collected specimens were measured to the nearest $0.1 \mathrm{~mm}$ using Vernier calipers. Temperature and salinity were measured at $2 \mathrm{~m}$ depth once a month with a Wissenschaftlich-Technische Werkstätten (WTW) multiline hydrographic probe (see Peharda et al. 2006).

For histological analysis of gonads, samples $(N=360)$ were fixed in Davidson solution and processed for routine histological preparation. Briefly, the tissue was dehydrated in increasing concentrations of ethanol, embedded in paraffin (Histowax, Leica), cut at 5-8 $\mu \mathrm{m}$ and stained by hematoxylin-eosin method. Each section was examined at 100 and 400× magnification, sexed and assigned to a development stage; i.e, inactive (0), early active (3), late active (4), ripe (5), partially spawned (2) and spent (1), according to Walker and Power (2004). A histological description of the particular gonad stages is given in Table 1 . The diameter of oocytes was measured using an Olympus C4040® zoom camera and Olympus DP-Soft $3.1{ }^{\circledR}$ program. For all monthly sampled female specimens, the diameter of all oocytes with visible nuclei within the visual field at $100 \times$ magnification $\left(\sim 1.22 \mathrm{~mm}^{2}\right)$ was measured.

In June, an additional sample consisting of 32 small individuals, ranging in length from 16.0 to $28.4 \mathrm{~mm}$, was histologically processed in order to determine whether $M$. barbatus adopt the protandric strategy in early life stages.
Fig. 1 Location of the Mali Ston Bay and site (filled circle) where $M$. barbatus specimens were collected for the study

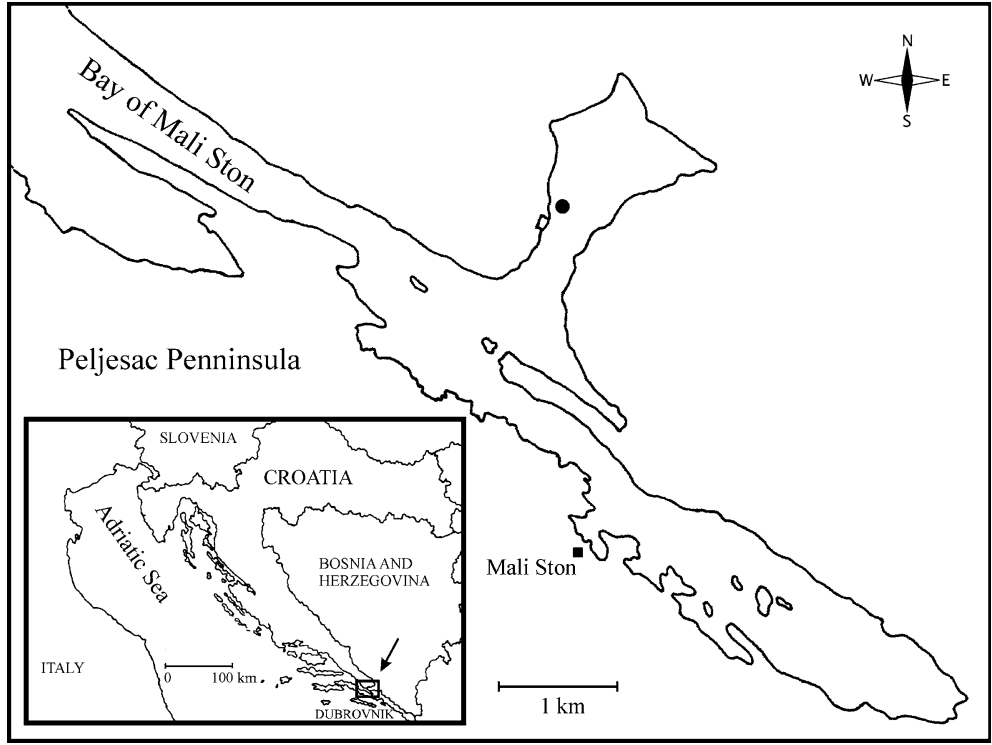


Table 1 Histological appearance of six gonad stages in M. barbatus

\begin{tabular}{|c|c|c|}
\hline & Female & Male \\
\hline Inactive & $\begin{array}{l}\text { Abundant connective tissue. Acini wall empty and } \\
\text { collapsed. Few undifferentiated germinative cells. } \\
\text { Phagocytes present. Sex determination hard }\end{array}$ & $\begin{array}{l}\text { Abundant dark purple connective tissue. Acini wall } \\
\text { empty and collapsed. Few undifferentiated } \\
\text { germinative cells. Phagocytes present. Sex } \\
\text { determination hard }\end{array}$ \\
\hline Early active & $\begin{array}{l}\text { Disseminated wide acini with monolayer of developing, } \\
\text { small oogonia and germinative cells attached to the } \\
\text { wall. Abundant connective tissue }\end{array}$ & $\begin{array}{l}\text { Dense connective tissue with islets of small compact } \\
\text { acini, filled with dark and large germinative cells and } \\
\text { first spermatogonia }\end{array}$ \\
\hline Late active & $\begin{array}{l}\text { Elongated or oval small acini. Oogonia in less number } \\
\text { attached to the acini wall, among large } \\
\text { previtellogenic and few vitellogenic oocytes }\end{array}$ & $\begin{array}{l}\text { Larger acini filled with spermatogonia on periphery and } \\
\text { spermatocytes centrally. Lumen pink from tails of } \\
\text { first spermatozoa }\end{array}$ \\
\hline Ripe & $\begin{array}{l}\text { Contracted interstitial connective tissue with flattened } \\
\text { cells and few phagocytes. Acini rounded, large filled } \\
\text { with attached and detached mostly vitellogenic } \\
\text { oocytes }\end{array}$ & $\begin{array}{l}\text { Light pink interstitial connective tissue stretched } \\
\text { between large elliptical acini, filled with basally } \\
\text { attached spermatogonia and spermatocytes. Acini } \\
\text { lumen filled with small spermatozoa, with } \\
\text { distinguishable pink tails in the acini center }\end{array}$ \\
\hline Partially spawned & $\begin{array}{l}\text { Only few layers of interstitial connective tissue. Most } \\
\text { postvitellogenic oocytes free in the acini lumen, with } \\
\text { large, light nucleus and small basophilic nucleolus }\end{array}$ & $\begin{array}{l}\text { Loose and abundant connective tissue surrounding } \\
\text { partially emptied acini, mainly filled with mature } \\
\text { spermatozoa }\end{array}$ \\
\hline Spent & $\begin{array}{l}\text { Loose and abundant connective tissue around empty } \\
\text { acini. Only few degenerating oocytes present. Acini } \\
\text { wall layered with phagocytes }\end{array}$ & $\begin{array}{l}\text { Collapsed and emptied acini throughout more compact } \\
\text { connective tissue. Remains of basally located } \\
\text { spermatozoa present with phagocytes }\end{array}$ \\
\hline
\end{tabular}

A mean gonad index was calculated for each sampling month to estimate the proportion of developing, ripe, spawning and spent individuals. It was obtained by multiplying the number of individuals from each developmental stage by the numerical ranking of that stage, and dividing the result by the total number of individuals in each sampling month (Gosling 2003).

For the analysis of the condition index, 30 specimens were processed monthly. The following parameters were measured for each specimen: dry flesh weight and wet weight of shell in grams $(\mathrm{g})$. Flesh was dried at $60^{\circ} \mathrm{C}$ to a constant weight and following condition index (C.I.) was calculated according to Davenport and Chen (1987):

C.I. $=($ dry flesh weight/shell weight $) \times 100$

Biochemical analysis was carried out on a tissue sample from five specimens per month each, consisting of the gonad tissue embedded throughout the digestive gland and the whole flesh. Crude extracts were prepared and the carbohydrate and protein contents were determined according to Saucedo et al. (2002). Both whole flesh and gonads were homogenized in cold saline solution $(35 \%$ $\mathrm{NaCl}$ ): 3 and $10 \mathrm{ml} / \mathrm{g}$ for whole flesh and gonads, respectively.

\section{Carbohydrate content}

Following addition of an equal amount of 20\% TCA to an aliquot of the crude extract, the mixture was centrifuged at
$4,000 \mathrm{rpm}$ for $15 \mathrm{~min}$ at $4^{\circ} \mathrm{C}$. Supernatant $(0.2 \mathrm{ml})$ was combined with anthrone reagent $(2 \mathrm{ml})$ and incubated for $2 \mathrm{~min}$ at $90^{\circ} \mathrm{C}$. Upon cooling at $4^{\circ} \mathrm{C}$, absorbance at $620 \mathrm{~nm}$ was determined against a blank prepared with distilled water instead of the sample. Carbohydrates were quantified against a calibration curve obtained with glucose standards.

\section{Protein content}

Aliquot of the saline crude extract was diluted sixfold with $0.5 \mathrm{M} \mathrm{NaOH}$ and allowed to stand for $24 \mathrm{~h}$. Protein concentration was determined using the Bradford assay with BSA as a standard.

\section{Lipid content}

The amount of lipid in the sample was determined according to Honkoop et al. (1999). The method was adapted for the determination of lipid content in saline crude extract. Instead of freeze-dried sample, saline crude extract $(20 \mu \mathrm{l})$ was combined with $2 \mathrm{ml}$ of concentrated sulfuric acid in a glass tube. An appropriate amount of the lipid standard needed for calibration curve was also mixed with $2 \mathrm{ml}$ of concentrated sulfuric acid in a glass tube. The tubes were heated for $10 \mathrm{~min}$ in water bath at $100^{\circ} \mathrm{C}$. After cooling, $50 \mu \mathrm{l}$ aliquots from each tube were mixed with $1 \mathrm{ml}$ of a reagent containing $11.9 \mathrm{M}$ phosphoric acid and $8 \mathrm{mM}$ vanillin (4-hydroxy-3 metoxybenzaldehyde). Absorbance was measured after $35 \mathrm{~min}$ at $530 \mathrm{~nm}$ against a blank containing $50 \mu \mathrm{l}$ of concentrated sulfuric acid 
instead of the sample. Length distribution with respect to sex was tested using the $t$-test. Prior to the analyses, data were tested for normality and homogeneity of variance. Chi-square goodness of fit was applied for sex ratio analysis. Spearman's correlation analysis was applied to describe the relationship between the reproductive cycle, condition index, biochemical composition and abiotic factors. A nonparametric Kruskal Wallis $H$ was used to test significant changes in the condition index over the sampling period, since variances were not homogeneous.

\section{Results}

Gonad samples were collected from a total of $360 \mathrm{M}$. barbatus, ranging in shell length from 30.0 to $65.5 \mathrm{~mm}$, with a mean of $44.9 \pm 6.0 \mathrm{~mm}$. There were no length differences between males and females $(F=0.07$, $P=0.793)$. However, the sex ratio differed from parity $\left(\chi^{2}=12.88, P<0.001\right)$, with significantly more females $(N=191)$ than males $(N=127)$. No hermaphrodites were found.

Nine samples got lost in the processing $(2.56 \%)$, and 33 samples $(9.40 \%)$, mostly in the January-March period $(N=26)$ could not be sexed. Interestingly, except during the spawning peak, all bivalves harboring sporocysts of the trematode Gymnophallus sp. showed delayed gonad development, which in some cases prevented sex differentiation.

The additional sample of small bivalves (June) showed a $1: 1$ sex ratio, with $12.5 \%$ of unidentifiable individuals $(N=4)$. The smallest individual $(16.0 \mathrm{~mm})$ was an early active male, suggesting that sexual maturation starts around this length. Most of the small females were "late active" (stage 4) (71.4\%), while 50\% of small males were "early active" (stage 3). While the reproductive stage of small females corresponded to that of larger females from the same month, the sexual development of small males in June was delayed by one stage compared to largest males.

At macroscopic observation male gonads are whitish, while sexually mature females have orange to red gonads. Gonad tissue surrounded the digestive gland and, in the late phase of sexual development, extended into the mantle. Microphotographs of the different reproductive stages are shown in Fig. 2.

January and February were characterized by sexual repose (Fig. 3). Early and late stages of sexual development were found in specimens collected between March and May. Spawning appears to be synchronous with a peak from June till August. During the spawning period, three different stages of gonad development (early, late active and ripe), were found in females, while males were either late active or ripe. Males also stayed ripe for a longer period of time, as in August some females were already partially spawned, while all males were still fully ripe. A small number of animals of both sexes spawned in October. The majority of animals sampled from September to December were partially spawned, while in a small percentage gametogenic development began already in September, however without a continuous pattern throughout February.

A significant correlation was noted between mean gonad index of males and females $(r=0.918, P<0.001)$. However, it appears that females start their gonad development earlier than males. It is interesting to note that more females than males were recorded in the period from January to March, which might simply be due to difficulties in determining the early phases of spermatogenesis.

Measured oocyte diameters (Fig. 4) ranged from 1 to $100 \mu \mathrm{m}$, with the means ranging from 9.3 (January) to $48.3 \mu \mathrm{m}$ (August), and with only a small number of oocytes $>80 \mu \mathrm{m}$. The mean diameter started to increase in February, showing an uneven growth, usually with a wide range of diameters in the same population. After May, the distribution of diameter frequencies reached a largely uniform pattern, with most oocytes ready for spawning and ranging in diameter around $50 \mu \mathrm{m}$. This pattern was stable until December when most females were still only partially spawned, and a small part of the population started the production of new oocytes.

High values of the mean gonad index were recorded for males and females in June and August, while the lowest values were obtained from September to February (Fig. 5). The sudden drop of the gonad index in both males and females coincided with the appearance of the first partially spawned individuals (July). It increased again in August when most of the bivalves were ripe, and it dropped again when the most part of the population had spawned. However, there is no straightforward correlation between the condition and the gonad index. There is however, a significant positive correlation between gonad index and temperature, and a negative correlation between gonad index and salinity (Table 2).

Low mean ratios of dry flesh weight and shell weight (<9) were recorded from December to March, and also from August to November. High values of the condition index $(>12)$ were recorded from April until July, and the highest mean value was observed in May (18.5) (Fig. 6). Monthly changes observed were statistically significant (Kruskal Wallis $H=208.64, P<0.001$ ).

Oscillations of stored nutrients were tightly coupled with the gametogenic cycle. Energy reserves accumulate during spring reaching a peak in May and June for lipids, and in May for carbohydrates. The most significant accumulation of lipids occurs in the gonad tissue, while carbohydrates accumulate approximately to the same 
Fig. 2 Light photomicrographs of the different histological gonad stages of female M. barbatus: a early active, b late active, $\mathbf{c}$ ripe, $\mathbf{d}$ partially spawned, e spent; and male M. barbatus: $\mathbf{f}$ early active, $\mathbf{g}$ late active, $\mathbf{h}$ ripe, $\mathbf{i}$ partially spawned, and $\mathbf{j}$ spent. Scale bar $200 \mu \mathrm{m}$
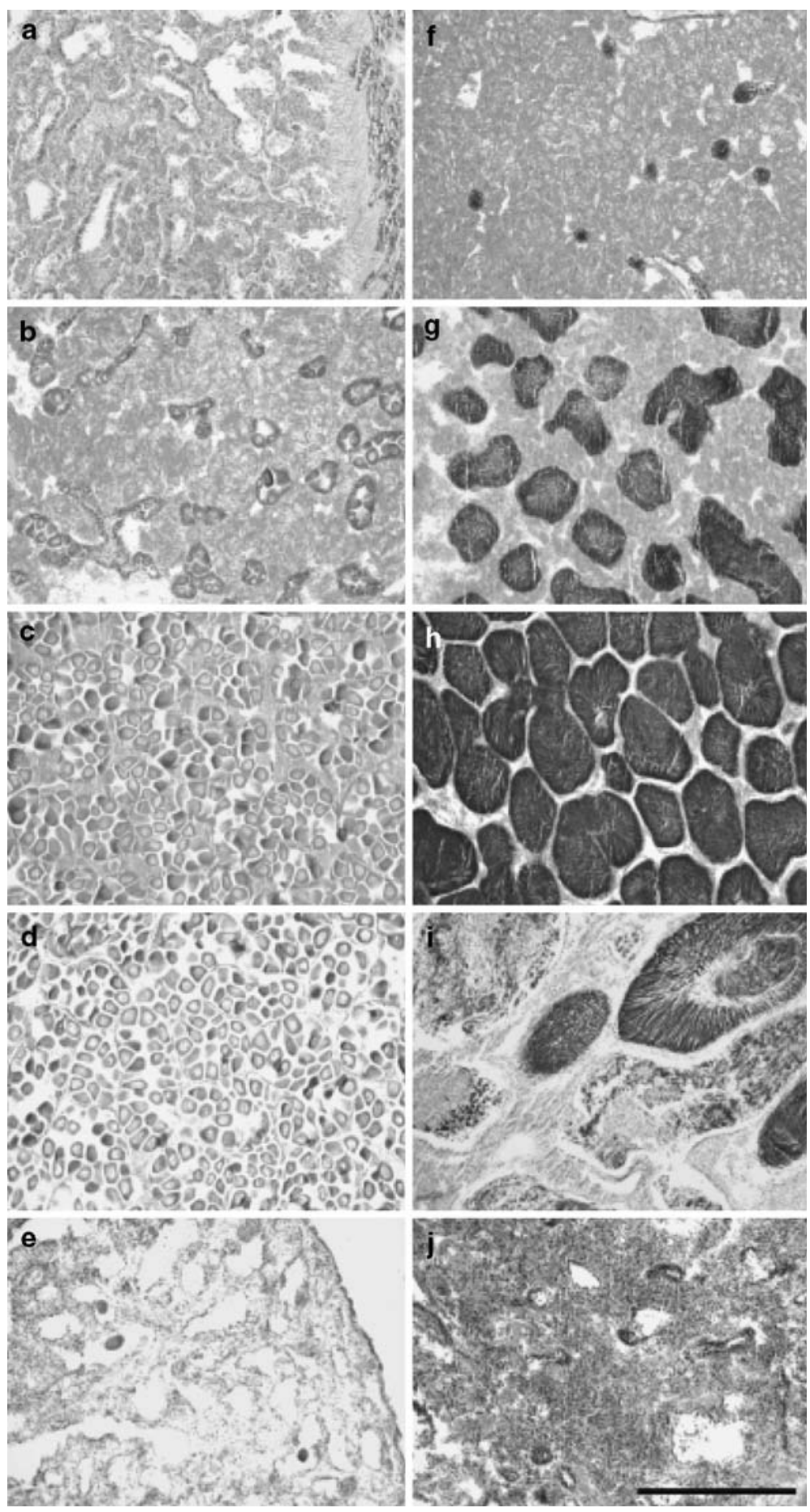

extent in gonad tissue and in whole flesh. A sudden decline of lipid content in the gonads is observed in July, followed by a period of stagnation until December. The decline in carbohydrate content that commences in June is more rapid in gonads than in whole shellfish flesh. Both gonads and whole flesh have lowest protein content in spring and the highest during the summer and autumn season. (Fig. 7)

\section{Discussion}

Bivalves exhibit a wide variation in the sex differentiation, ranging from strict gonochorism through intermediate form to functional hermaphrodites (Sastry 1979).

Horse-bearded mussel from the south Adriatic is a purely dioecious species, though members from the same genus such as M. modiolus from the North Irish Sea and the 

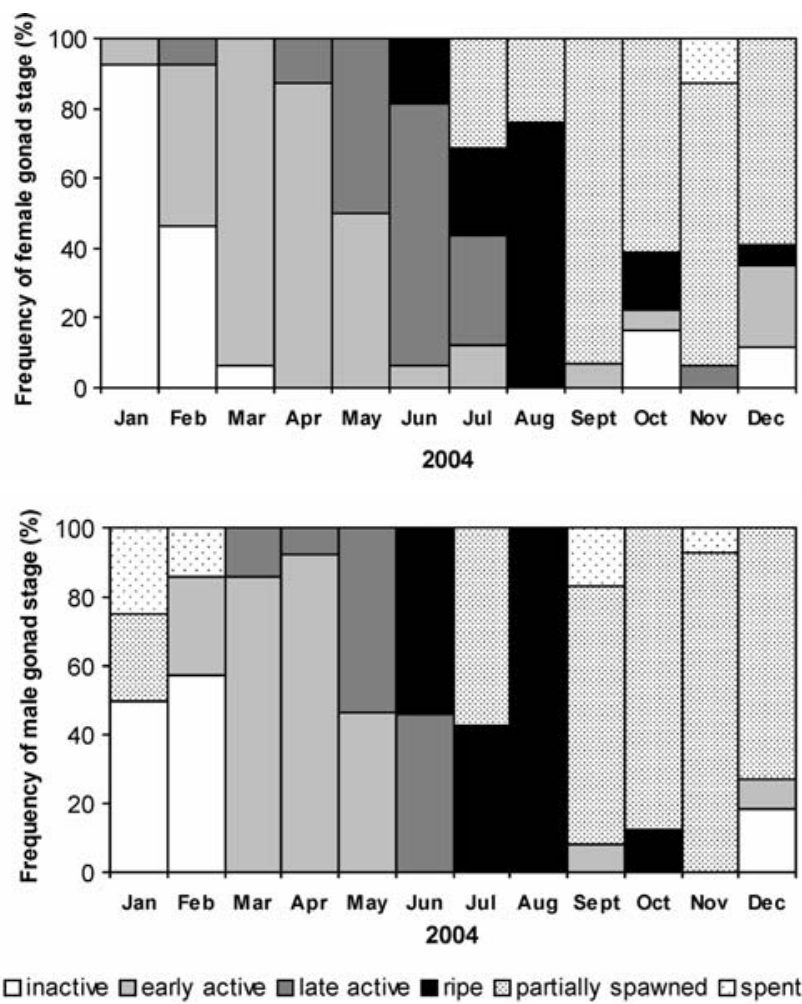

Fig. 3 The relative frequency of the different gonad stages of $M$. barbatus females and males over the study period

Mediterranean, exhibit a small percentage of hermaphrodic individuals (Cahour and Lucas 1968; Jasim and Brand 1989).

A similar variation was found with respect to the sex ratio: while $M$. barbatus in the Adriatic Sea is slightly female biased, M. modiolus in the North Irish Sea has an equal sex ratio, and the same was observed in small horsebearded mussels. Sastry (1979) suggested that deviation from an equal sex ratio is mainly the result of sex reversal, as was observed in Noah's Arc (Arca noae) (Peharda et al. 2006). Authors observed a predominance of males at younger age or smaller sizes, followed by a dominance of females. Besides from sex reversal, changes in the sex ratio with age/size can result from sex-specific differences in mortality (Seed 1969) or growth rate (Gribben et al. 2004).

Generally, spawning in bivalves is either continuous or seasonal. (Caballos-Vazquez et al. 2000). Horse-bearded mussels have an annual reproductive cycle that involves a prolonged period of gametogenesis, followed by an extended spawning season. This is typical of many benthic marine invertebrates in northern temperate zones (Maloy et al. 2003). Gametogenesis starts in February, and spawning occurs between June and August. On average, females start sexual development earlier in the year, but males enter the ripe stage slightly prior to female and stay ripe for a longer period of time. This may be related to lower energy costs of gametogenesis for males than for females (Ropes et al. 1984). An earlier annual start of sexual development in females than in males was also recorded in small individuals of the horse-bearded mussel, while the opposite was recorded from the New Zealand venus clam (Ruditapes largillierti) (Gribben et al. 2001) and the New Zealand geoduck (Panopea zelandica) (Gribben et al. 2004).

There was a rather extended phase of the annual cycle with ripe specimens present in the studied population. Even after August when most individuals were spent, there was a small part of them (especially among females) which was still ripe. This extended breeding season seems to be an essential condition for successful reproduction (Eversole 1989). While in M. barbatus, the occurrence of ripe males seems to be slightly better synchronized than that of ripe females, the inverse situation was reported from cholga paleta (Atrina seminude) (Soria et al. 2002).

In specimens infected by sporocysts of the trematode Gymnophallus sp., gonad development was retarded to some extent. This infection can result in castration of the host and is known from numerous bivalve species (e.g., Taskinen et al. 1997; Khamdan 1998; Taskinen 1998; Da Silva et al. 2002). However, because of low parasite prevalences and abundances, trematode infection does not seem to present a major threat to horse-bearded mussel populations and their possible introduction into aquaculture system (Mladineo and Peharda 2006).

In M. modiolus the temporal pattern of spawning differs strongly among geographical populations and may depend on environmental factors (Brown 1984). Individuals can spawn in a single event within 1 day, or intermittently throughout the year (Jasim and Brand 1989). Such variability in the timing of spawning could occur also in $M$. barbatus, however, nothing is known on the reproductive behavior of other horse-bearded mussel populations in the Atlantic and the Mediterranean. Differences in the reproductive pattern within the same species were observed in other bivalves as well (Rodhouse et al. 1984; Peharda et al. 2006), and are suggested to be a constructive characteristic for the implementation of a profitable aquaculture, as in this way their broodstocks may be available over a broader time-scale (Gribben et al. 2004).

The oocyte diameter is an excellent descriptor of the reproductive cycle, congruent with the gametogenic stage; it is influenced by the environmental stress, age and the life strategy (Honkoop and van der Meer 1998; Toro et al. 2002; Maloy et al. 2003). Like in other bivalves (GarciaDominguez et al. 1998; Gribben et al. 2004; Peharda et al. 2006), the biggest oocytes in the horse-bearded mussel are found in ripe and partially spawned individuals. However, compared to other mytilids, oocytes of $M$. barbatus have a 
Fig. 4 Frequency histograms of oocyte diameters of $M$. barbatus over the study period
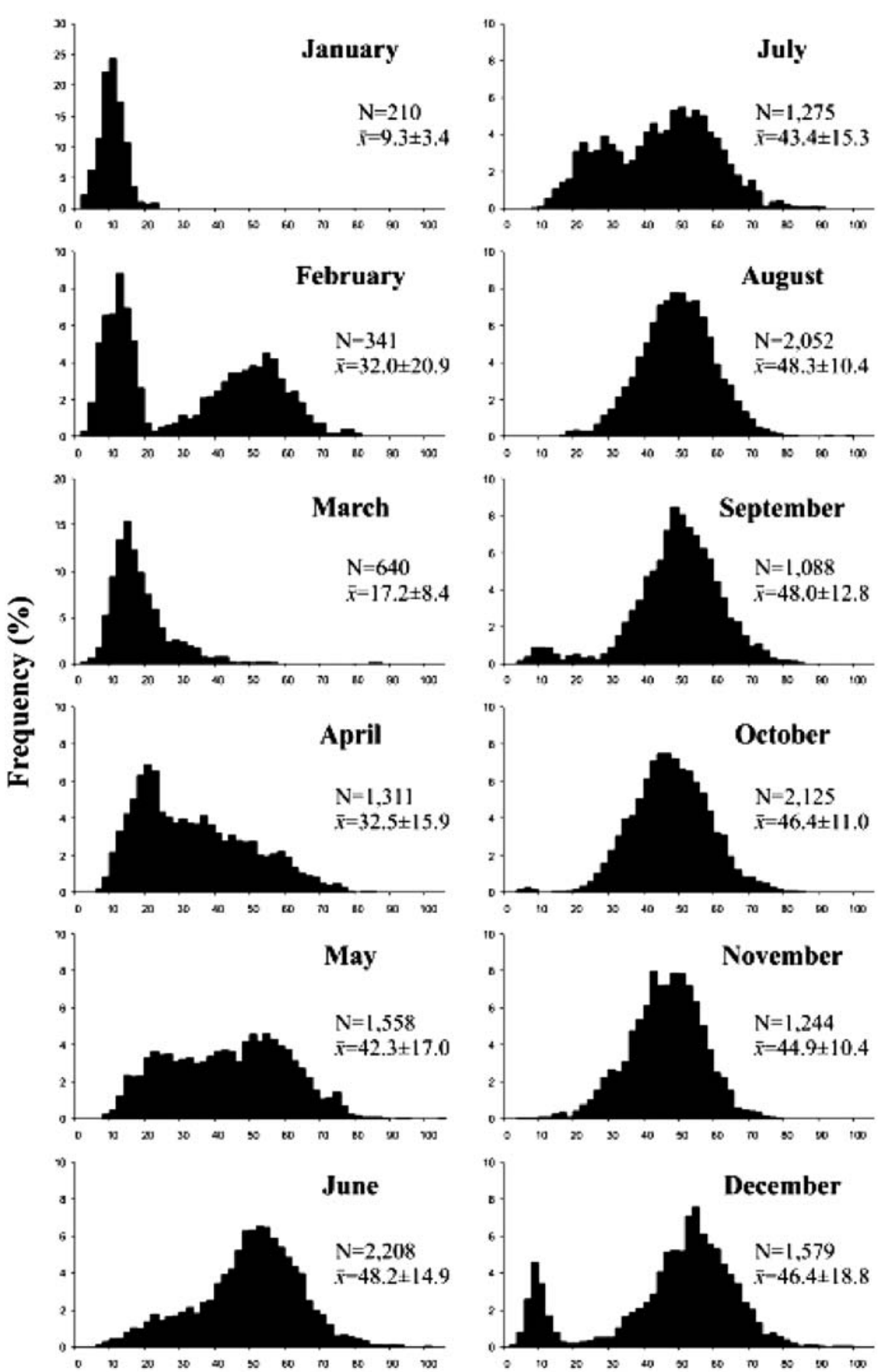

Oocyte diameter $(\mu \mathrm{m})$ smaller maximum mean diameter (Honkoop and van der Meer 1998; Maloy et al. 2003). This implicates a lower larval survival and growth rate in horse-bearded mussel than in bivalves with bigger oocytes (Kraeuter et al. 1982). In a sheltered environment such as the Mali Ston Bay, the production of small eggs may be favored, because high autumn temperatures and algal concentrations allow for a high growth rate of larvae, similar to cases when larvae are released much earlier in the year (Honkoop and van der Meer 1998). The frequency distributions of oocyte diameters clearly demonstrate that there is a single, extended annual spawning period in the studied population. The secondary peak of oocyte diameter shown in February however, consisted of a smaller number of spawned females with athretic folliculi in the process of reabsorption. 


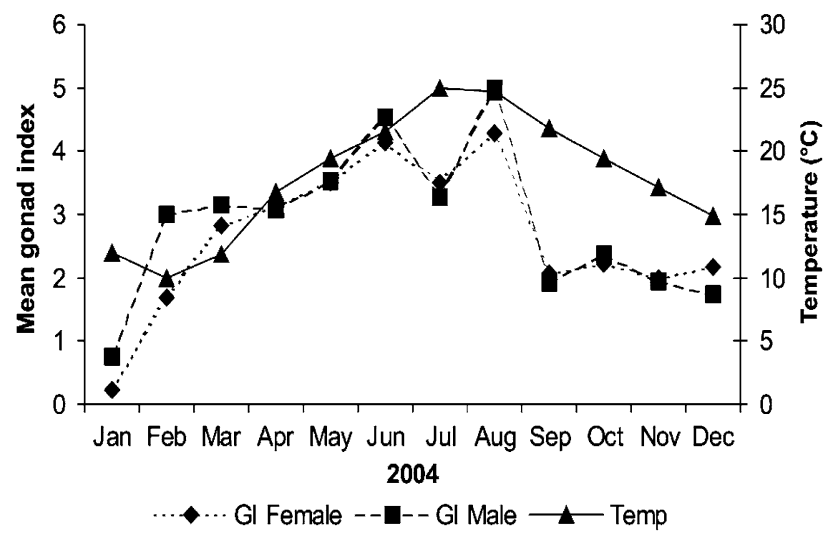

Fig. 5 Mean gonad indices of M. barbatus and temperature over the study period

The condition index is regarded as the most sensitive to changes in the reproductive development, and usually correlates well with the mean gonad index (Ojea et al. 2004; Peharda et al. 2006). Their determination was even suggested as a quick method to assess broodstock reproductive state (Gribben et al. 2004). Even though the condition index generally followed the reproductive stages in horse-bearded mussels, reflecting indeed the outset of spawning, it did not tightly correlate with the gonad index. This may be due to the fact that in any given month, among both males and females, we found individuals of different gonadal stage. In December, for example, most females were partially spawned, but others were inactive, early active and even ripe. This may explain the missing correlation between condition and gonad index. The highest mean condition index was recorded from April to July which coincides with the highest abundance of microphytoplankton (Jasprica and Carić 1997). In general,

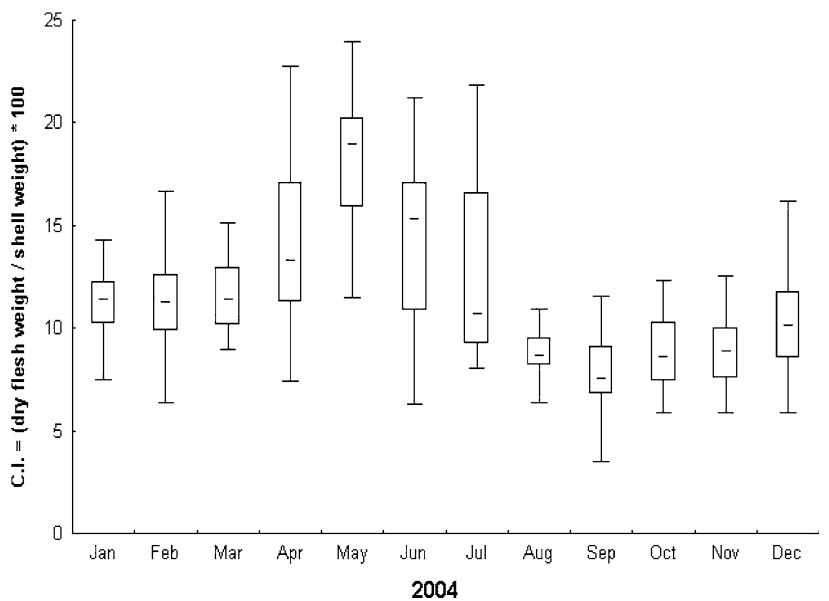

Fig. 6 Mean condition indices (ratios of dry flesh weight and shell weight) in $M$. barbatus over the study period

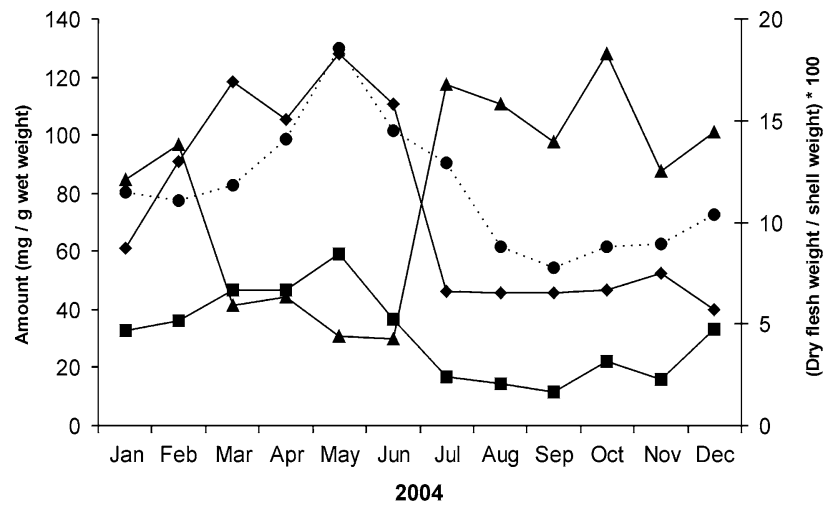

Fig. 7 Protein (filled triangle), lipid (filled diamond) and carbohydrate (filled square) contents and condition index expressed as ratio of dry flesh weight and shell weight (filled circle) in M. barbatus over the study period. The amount of the biochemical components is expressed as milligram of the respective component in one gram of gonads (wet weight)

Table 2 Spearman's correlation analysis between condition index, gonad index, biochemical components of the digestive gland of M. barbatus and abiotic factors (temperature, salinity)

\begin{tabular}{|c|c|c|c|c|c|c|}
\hline & Condition index & Gonad index & Lipids & Carbohydrates & Proteins & Temperature \\
\hline \multirow[t]{2}{*}{ Gonad index } & $r=0.350$ & & & & & \\
\hline & $P=0.265$ & & & & & \\
\hline \multirow[t]{2}{*}{ Lipids } & $r=0.782$ & $r=0.236$ & & & & \\
\hline & $P=0.003$ & $P=0.461$ & & & & \\
\hline \multirow[t]{2}{*}{ Carbohydrates } & $r=0.815$ & $r=0.032$ & $r=0.874$ & & & \\
\hline & $P=0.001$ & $P=0.921$ & $P<0.001$ & & & \\
\hline \multirow[t]{2}{*}{ Proteins } & $r=-0.743$ & $r=-0.255$ & $r=-0.906$ & $r=-0.796$ & & \\
\hline & $P=0.006$ & $P=0.425$ & $P<0.001$ & $P=0.002$ & & \\
\hline \multirow[t]{2}{*}{ Temperature } & $r=-0.010$ & $r=0.731$ & $r=-0.307$ & $r=-0.479$ & $r=0.207$ & \\
\hline & $P=0.976$ & $P=0.007$ & $P=0.332$ & $P=0.115$ & $P=0.518$ & \\
\hline \multirow[t]{2}{*}{ Salinity } & $r=-0.410$ & $r=-0.771$ & $r=-0.177$ & $r=-0.052$ & $r=0.131$ & $r=-0.602$ \\
\hline & $P=0.186$ & $P=0.003$ & $P=0.581$ & $P=0.873$ & $P=0.685$ & $P=0.038$ \\
\hline
\end{tabular}

Significant values are indicated in bold 
reproduction is strongly influenced by temperature and food availability (Rodhouse et al. 1984; Gosling 2003). Consequently, we found the gonad index of $M$. barbatus to be strongly correlated with these exogenous factors. It is interesting to note that another bivalve, arcid Arca noae, present at the same localities as the horse-bearded mussel, and thus exposed to the same abiotic factors, showed no statistical correlation between temperature and gonad index (Peharda et al. 2006).

Gametogenesis is an energy-demanding process, and generally two main strategies of energy utilization are recognized in bivalves (Bayne 1976). The energy of ingested food can be utilized either directly or indirectly, i.e., by mobilization of storage products synthesized during the growing season. Gametogenesis in M. edulis relies on both sources: gametogenesis starts in autumn at the expense of stored nutrients; when in winter temperature drops, the process is delayed, and is finally finished in the new growing season, using also ingested food as energy source (Honkoop and van der Meer 1998). Spawning of $M$. barbatus results in deprivation of energy stores in form of carbohydrates and lipids. A rapid decline of lipid content in gonads during spawning may be explained by a loss of lipids stored in ripe eggs, while the earlier onset and somewhat slower reduction in carbohydrate content may be due to its increased utilization in the final stages of maturation. As energy accumulates in form of both lipids and carbohydrates simultaneously in early stages of gametogenesis, gametogenesis in M. barbatus may rely, for the most part, directly on the energy of ingested food. Variations in protein content reflect changes in the amount of energy storage compounds; lowest values coincide with maxima of carbohydrate and lipid contents, and the highest values are attained when these products are utilized. When food is abundant such as in the summer months, surplus of energy is used for gonad and somatic development.

Acknowledgments This research was financed by the Croatian Ministry of Science and Technology. The authors are grateful to Gregorio Biggatti for his advices, and Željko Baće, Nikša Glavić, Marko Žarić, Lovorka Kekez, Zvjezdana Popović, Nika Stragličić and Mark Prime for technical assistance.

\section{References}

Bayne BL (1976) Aspects of reproduction in bivalve mollusks. In: Wiley ML (ed) Estuarine processes. Academic, New York, pp 432-448

Benović A (1997) The history, present condition, and future of the molluscan fisheries of Croatia. In: MacKenzie CL Jr, Burrell VG Jr, Rosenfield A, Hobart WL (eds) The history, present condition, and future of the molluscan fisheries of North and Central America and Europe, vol 3. NOAA Technical Report NMFS 129. U.S. Department of Commerce, Europe, pp 217-226
Brown RA (1984) Geographical variations in the reproduction of the horse mussel, Modiolus modiolus (Mollusca: Bivalvia). J Mar Biolog Assoc UK 64:751-770

Caballos-Vazquez BP, Arellano-Martinez M, Garcia-Dominguez F, Villalejo-Fuerte M (2000) Reproductive cycle of the rugose pen shell, Pinna rugosa Sowerby, 1835 (Mollusca: Bivalvia) from Bahia Concepcion, Gulf of California and its relation to temperature and photoperiod. J Shellfish Res 19:95-99

Cahour A, Lucas A (1968) Sex ration of hermaphrodisme accidental chez Modiolus barbatus (L) Mollusque Bivalve. CR Hebd Seances Acad Sci Paris 162:221

Darrigran G, Renchaszadeh P, Damborenea MC (1999) The reproductive cycle of Limnoperna fortunei (Dunker, 1857) (Mytilidae) from neotropical temperate locality. J Shellfish Res 18:361-365

Da Silva PM, Magalhaes ARM, Barracco MA (2002) Effects of Bucephalus sp. (Trematoda: Bucephalidae) on Perna perna mussels from culture station in Ratones Grande Island, Brazil. J Invertebr Pathol 79:154-162

Davenport J, Chen XG (1987) A comparison of methods for the assessment of condition in the mussel (Mytilus edulis L.). J Moll Stud 53:293-297

Eversole AG (1989) Gametogenesis and spawning in North American clam populations: implications for culture. In: Manzi JJ, Castagna M (eds) Developments in aquaculture and fisheries science, Clam mariculture in North America, vol 19. Elsevier, Amsterdam, pp 75-109

Garcia-Dominguez F, Ceballos-Vazquez BP, Villalejo-Fuerte M, Arellano-Martinez M (1998) Reproductive cycle of the giant reef clam Periglypta multicostata (Sowerby, 1835) (Pelecypoda: Veneridae) at isla Espiritu Santo, Baja California Sur, Mexico. J Shellfish Res 17:1009-1013

Gosling E (2003) Bivalve molluscs—biology, ecology and culture. Fishing News Books, Oxford

Gribben PE, Creese RG, Hooker SH (2001) The reproductive cycle of the New Zealand venus clam Ruditapes largillierti. J Shellfish Res 20:1101-1108

Gribben PE, Helson J, Jeffs AG (2004) Reproductive cycle of the New Zealand Geoduck, Panopea zelandica, in two North Island populations. Veliger 47:53-65

Honkoop PJC, van der Meer J (1998) Experimentally induced effects of water temperature immersion time on reproductive output of bivalves in the Wadden Sea. J Exp Mar Biol Ecol 220:227-246

Honkoop PJC, van der Meer J, Beukema JJ, Kwast D (1999) Reproductive investment in the intertidal bivalve Macoma balthica. J Sea Res 41:203-212

Jasim AK, Brand AR (1989) Observations on the reproduction of Modiolus modiolus in Isle of Man waters. J Mar Biolog Assoc UK 69:373-385

Jasprica N, Carić M (1997) A comparison of phytoplankton biomass estimators and their environmental correlates in the Mali Ston Bay (Southern Adriatic). Mar Ecol PSZN 18:35-50

Khamdan SAA (1998) Occurrence of Bucephalus sp. trematode in the gonad of the pearl oyster Pinctada radiata. Environ Int 24:117120

Kraeuter JN, Castagna M, van Dessel R (1982) Egg size and larval survival of Mercenaria mercenaria (L.) and Agropecten irradians (Lamarck). J Exp Mar Biol Ecol 56:3-8

Lepennec M (1997) Feeding and reproduction of marine bivalve mollusks in reduced habitats. Annee Biol 36:155-164

Maloy AP, Barbera BJ, Rawson PD (2003) Gametogenesis in a sympatric population of blue mussels, Mytilus edulis and Mytilus trossulus, from Cobscook Bay (USA). J Shellfish Res 22:119123

Mladineo I, Peharda M (2006) Histopathology of Gymnophallus sp. sporocysts in edible mytilid Modiolus barbatus. J Shellfish Res 24:1097-1100 
Ojea J, Pazos AJ, Martínez D, Novoa S, Sánchez JL, Abad M (2004) Seasonal variation in weight and biochemical composition of the tissues of Ruditapes decussatus in relation to the gametogenic cycle. Aquaculture 238:451-469

Peharda M, Bolotin J, Vrgoč N, Jasprica N, Bratoš A, Skaramuca B (2003) A study of Noah's Ark shell (Arca noae Linnaeus 1758) in Mali Ston Bay, Adriatic Sea. J Shellfish Res 22:705-709

Peharda M, Mladineo I, Bolotin J, Kekez L, Skaramuca B (2006) The reproductive cycle and potential protandric development of the Noah's Ark shell, Arca noae L.: implications for aquaculture. Aquaculture 252:317-327

Poppe G, Goto Y (1993) European seashells, vol II (Scaphopoda, Bivalvia, Cephalopoda). ConchBooks, Hackenheim

Rodhouse PG, Roden CM, Burnell GM, Hensey MP, McMahom T, Ottway B, Ryan TH (1984) Food resources, gametogenesis and growth of Mytilus edulis on the shore and in suspended culture: Killary Harbour, Ireland. J Mar Biolog Assoc UK 64:513-529

Ropes JW, Murawski SA, Serchuk FM (1984) Size, age, sexual maturity and sex ratio in ocean quahogs, Arctica islandica Linne, off Long Island, New York. Fish Bull 82:253-267

Sastry AN (1979) Pelecypoda (excluding Ostreidae). In: Giese N, Pearse JS (eds) Reproduction of marine invertebrates, vol 4. Academic, New York, pp 113-292

Saucedo P, Racotta I, Villarreal H, Monteforte M (2002) Seasonal changes in the histological and biochemical profile of the gonad, digestive gland, and muscle of the calafia mother-of-pearl oyster, Pinctada mazatlantica (Hanley, 1856) associated with gametogenesis. J Shellfish Res 21:127-135

Seed R (1969) The ecology of Modiolus modiolus (L.) (Lamellibranchiata) on exposed rocky shores. I. Breeding and settlement. Oecologia 3:277-316
Sgro L, Turolla E, Rossi R, Mistri M (2002) Sexual maturation and larval development of the immigrant Asian date mussel, Musculista senhousia, in a Po River deltaic lagoon. Ital J Zool 69:223-228

Soria RG, Pascual MS, Fernandez Cartes VH (2002) Reproductive cycle of the cholga paleta, Atrina seminude Lamarck, 1819 (Bivalvia: Pinnidae) from Northern Patagonia, Argentina. J Shellfish Res 21:479-488

Taskinen J (1998) Influence of trematode parasitism on the growth of a bivalve host in field. Int J Parasitol 28:599-602

Taskinen J, Makela T, Valtonen ET (1997) Exploitation of Anodonta piscinalis (Bivalvia) by trematodes: parasite tactics and host longevity. Ann Zool Fenn 34:37-46

Thompson RJ (1984) The reproductive cycle and physiological ecology of the mussel Mytilus edulis in a subarctic, non-estuarine environment. Mar Biol 79:277-288

Toro JE, Thompson RJ, Innes DJ (2002) Reproductive isolation and reproductive output in two sympatric mussel species (Mytilus edulis, M. trossulus) and their hybrids from Newfoundland. Mar Biol 141:897-909

Turolla E, Castaldelli, Barbin L, Rossi R (2002) Guida alla riproduzione controllata di Modiolus barbatus. University of studies of Ferrara, Italy. Department of Biology, CRiM Centro recherche sui molluschi

Walker RL, Power AJ (2004) Growth and gametogenic cycle of the transverse ark, Anadara transversa (Say, 1822), in coastal Georgia. Am Malacol Bull 18:55-60 